\title{
Characteristics of Carbohydrate Metabolism in Sweet Corn (sugary-1) Endosperms
}

\author{
Douglas C. Doehlert ${ }^{1}$ and Tsung Min Kuo \\ U.S. Department of Agriculture, Agricultural Research Service, National Center for Agricultural \\ Utilization Research, Phytoproducts Research Unit, 1815 North University Street, Peoria, IL 61604
}

John A. Juvik

Department of Horticulture, University of Illinois, 1201 West Gregory Avenue, Urbana, IL 61801

Eric P. Beers and Stanley H. Duke

Department of Agronomy, University of Wisconsin, 1575 Linden Drive, Madison, WI 53706

\begin{abstract}
Additional index words. Zea mays, phytoglycogen, gene dosage
Abstract. Metabolic characteristics of developing sugary-I maize (Zea mays L.) endosperms were investigated. In the later stages of development (>30 days postpollination), sugary-1 kernels maintained higher levels of many enzyme activities and retained more moisture than normal kernels. Higher enzyme activities were attributed to moisture retention and were not associated with any increase in dry weight accumulation. Of enzyme activities measured at 20 days postpollination, that of ADP-glucose pyrophosphorylase was higher in sugary-1 kernels than in normal, whereas total amylase, a-amylase, and pullulanase activities were lower. Experiments testing the effects of zero, one, two, and three doses of the sugary-1 gene in $\mathbf{O H} 43$ endosperms indicated that the sugary-1 phenotype was not expressed until three doses of the sugary-1 gene were present. Decreased activities of amylases, but not of pullulanase, were attributed to an interference in detection by phytoglycogen. Increased ADP-glucose pyrophosphorylase activity is attributed to a response by the maize endosperm cells to increased sucrose concentrations.
\end{abstract}

The sugary- 1 genotype of maize (Zea mays), commonly grown as sweet corn, accumulates more sugars in the endosperm than normal starchy maize. The principle difference between normal and sugary- 1 maize is that sugary- 1 endosperms accumulate the highly branched, water soluble form of starch known as phytoglycogen (Morris and Morris, 1939). There are two hypotheses concerning the origin of phytoglycogen. The first suggests that sugary- 1 maize kernels lack sufficient starch debranching enzyme (Erlanger, 1957). This hypothesis suggests that starch biosynthesis involves the synthesis of a highly branched intermediate form of starch which is subsequently debranched to form the amylose and amylopectin found in normal maize starch granules. Evidence supporting this hypothesis was provided by Pan and Nelson (1984), who demonstrated significantly reduced pullulanase activity (one form of starch debranching enzyme found in developing maize kernels) in sugary- 1 kernels that appeared to depend on the sugary- 1 gene dosage.

The second hypothesis suggests that the sugary- 1 mutation affects a starch-branching enzyme, which results in the more highly branched phytoglycogen (Boyer and Preiss, 1978). The sugary- 1 mutation has many additional effects on maize kernel development. Amyloplasts fail to form birefringent starch granules and instead accumulate phytoglycogen (Boyer et al., 1977). In comparison to normal kernels, sugary- 1 kernels accumulate less dry weight (Andrew et al., 1944; Tsai et al., 1978), retain kernel moisture longer (Andrew et al., 1944), have thinner pericarp (Andrew et al., 1944) and contain altered storage protein (Tsai et al., 1978).

In this study, we have investigated developmental and dosage effects of the sugary- 1 gene on carbohydrate metabolism in the

Received for publication 1 Sept. 1992. Accepted for publication 12 Jan. 1993. The cost of publishing this paper was defrayed in part by the payment of page charges. Under postal regulations, this paper therefore must be hereby marked advertisement solely to indicate this fact.

${ }^{1}$ To whom reprints requests should be addressed. maize kernel. Our results provide some additional insights into the nature of the sugary- 1 mutation and contribute information on the functioning of the normal maize kernel.

\section{Materials and Methods}

Plant material. Inbred and hybrid maize lines were grown in the field in Peoria, Ill., during 1986-88. Normal and sugary- 1 isolines of $\mathrm{OH} 43$ were obtained from the Maize Genetics Cooperative of the Univ. of Illinois, Agronomy Dept., Urbana. Normal and sugary- 1 isolines of W64A were obtained from L. Darrah, (Univ. of Missouri, Columbia). Plants grown in the field were handpollinated and harvested at designated time intervals. Samples were taken in a randomized design with three or four replications. For enzyme extractions and carbohydrate analyses, immature kernels were stripped from harvested ears, dissected, and about thirty endosperms were lyophilyzed and stored at $-80 \mathrm{C}$ until used. Whole kernels also were stripped from freshly harvested ears and frozen at $-80 \mathrm{C}$ until used. Kernel dry weights and moisture content were determined after drying in a forced air oven at $60 \mathrm{C}$ for $72 \mathrm{~h}$.

Enzyme assays and carbohydrate analysis. Extraction and assays of enzymes were performed as described by Doehlert et al. (1988) and Doehlert and Kuo (1990). Enzymes were extracted by homogenizing $0.2 \mathrm{~g}$ powdered lyophilized tissue in $4 \mathrm{ml}$ extraction buffer containing (in mM) 50 HEPES ( $\mathrm{pH} \mathrm{7.2),} 5 \mathrm{MgCl}_{2}$, and 5 dithiothreitol. Particulates were settled by centrifugation of the homogenate at $10,000 \times \mathrm{g}$ for $15 \mathrm{~min}$.

The enzymes sucrose synthase (EC 2.4.1.13), pyrophosphate: n-fructose 6-phosphate, 1-phosphotransferase (EC 2.7.1.90; PFP), UDP-Glc pyrophosphorylase (EC 2.7.7.9), ADP-Glc pyrophos-

Abbreviations: ADP-Glc, adenosine diphosphate glucose; DPP, days postpollination; HEPES, N-2-hydroxyethylpiperazine-N'-2-ethanesulfonic acid; PFK, phosphofructokinase; PFP, pyrophosphate: fructose-6-phosphate, 1-phosphotransferase; UDP-Glc, uridine diphosphate glucose. 
phorylase (EC 2.7.7.27), aldolase (EC 4.1.2.13), NAD-dependent sorbitol dehydrogenase (EC 1.1.1.14), phosphoglucoisomerase (EC 5.3.1.9), phosphoglucomutase (EC 2.7.5.1), phosphofructokinase (EC 2.7.1.11), glucokinase (EC 2.7.1.11), and fructokinase (EC 2.7.1.4) were assayed by continuous spectrophotometric assays where the reaction product was coupled with either NAD reduction or NADH oxidation and monitored by $\mathrm{A}_{340}$ as described by Doehlert (1990) and Doehlert et al. (1988).

Pullulanase (EC 3.2.1.41) was assayed by the procedure of Doehlert and Knutson (1991). Assays contained $50 \mathrm{~mm}$ acetate$\mathrm{NaOH}$ (pH 5.0), $5 \mathrm{~mm} \mathrm{MgCl}_{2}$, and $2.5 \%$ pullulan (w/v). Samples were taken at $0,10,20$, and $30 \mathrm{~min}$. Reducing power of the sample was determined with dinitrosalicylic acid solution (Bernfield, 1951), and compared with a maltotriose standard curve. An additional blank was used containing enzyme extract but no pullulan to correct for the contribution of hydrolyzed phytoglycogen to the increase in reducing power. Total amylase activity was assayed by measuring the increase of reducing power in a solution of soluble starch. Assays contained $50 \mathrm{~mm}$ citrate $(\mathrm{pH}$ 6.0) and 5\% soluble starch (w/v). Assays were terminated after $10 \mathrm{~min}$, and the reducing power was measured with dinitrosalicylic acid solution (Bernfield, 1951). The $\alpha$-amylase activity was assayed by the starch azure method (Doehlert and Duke, 1983). Assays contained (in $\mathrm{mM}$ ) 50 citrate buffer ( $\mathrm{pH} \mathrm{6.0),} 5$ dithiothreitol, $2 \mathrm{CaCl}_{2}$, and 20 $\mathrm{g}$ starch azure/liter. Interference by $\beta$-amylase was eliminated by adding 1000 units sweet potato $\beta$-amylase $/ \mathrm{ml}$. The solubilized blue pigment indicative of $\alpha$-amylase activity was measured at 595 $\mathrm{nm}$ and was compared with that released by known activities of bacterial $\alpha$-amylase in the presence of 1000 units $/ \mathrm{ml}$ sweet potato $\beta$-amylase. Doehlert and Knutson (1991) indicated that starch debranching enzyme activities had no effect on the starch azure assay.

All enzyme assays were conducted at 30C. One unit of activity is defined as the activity necessary to produce $1 \mu \mathrm{mol}$ of product in $1 \mathrm{~min}$ at $30 \mathrm{C}$.

Staining of electrophoretic gels for starch hydrolytic activity was performed by electrophoretic transfer of proteins from a native polyacrylamide gel onto a starch-containing gel, followed by KI$\mathrm{I}_{2}$ staining using the method of Kakefuda and Duke (1984) as modified by Beers and Duke (1988). The $\alpha$ - and $\beta$-amylases were identified by electrophoretic transfer onto gels containing $\beta$ - limit dextrin. The $\beta$-limit dextrin was prepared by the method of Swain and Dekker (1966).

To test the effects of phytoglycogen on the activities of starch hydrolytic enzymes, $10 \mathrm{mg}$ of phytoglycogen $/ \mathrm{ml}$ was added to a set of three samples of normal 20-days postpollination (DPP) whole $\mathrm{OH} 43$ kernel extracts, and an equal volume of water was added to a control set. All samples were then centrifuged at 30,000 $\times \mathrm{g}$ for 20 min. Subsequent to centrifugation, all samples were assayed for activities of starch hydrolytic enzymes.

Soluble sugars were extracted and identified by high pressure liquid chromatography as described by Kuo et al. (1988). Total (1:4),(1:6) $\alpha$-D-glucan (starch + phytoglycogen) was determined on 50-mg samples. Samples were washed three times with $70 \%$ ethanol $(\mathrm{v} / \mathrm{v})$ to remove soluble sugars. The washed pellets were then suspended in $5 \mathrm{ml}$ of $400 \mathrm{~mm}$ acetate buffer ( $\mathrm{pH} 5.0$ ) and heated to $90 \mathrm{C}$ for $90 \mathrm{~min}$ to gelatinize the starch. Twenty units of amyloglucosidase (Sigma \#A-9268) were added to each sample along with $\mathrm{NaF}$ to a final concentration of $10 \mathrm{~mm}$ to prevent microbial growth, and samples were allowed to incubate at $40 \mathrm{C}$ for $48 \mathrm{~h}$. Samples were centrifuged at $1200 \times \mathrm{g}$ for $2 \mathrm{~min}$, and supernatants were placed in respective $50-\mathrm{ml}$ volumetric flasks. Pellets were rinsed twice and centrifuged, supernatants were pooled and brought up to $50 \mathrm{ml}$, and glucose concentrations were determined with the glucose oxidase method (Gascon and Lampen, 1968). Soluble sugars, phytoglycogen, and starch in mature sugary -1 gene dosage series kernels were fractionated by the procedure described by Dickinson et al. (1983) and quantitated by the phenol sulfuric acid method (Hodge and Hofrieter, 1962). Phytoglycogen was purified from OH43 sugary- 1 kernels by the method of Schoch (1957).

Student's $t$ tests and analyses of variance were performed with the ABSTAT (Anderson Bell, Parker, Colo.) computer statistics package. Least significant differences were calculated by the method described by Steel and Torrie (1960).

\section{Results and Discussion}

During kernel development, sugary- 1 kernels had significantly higher fresh weight than normal kernels $(P>0.01$; Table 1$)$ from 10 through 35 DPP, and had significantly lower dry weight from 20 DPP to maturity $(P>0.05$, Table 1$)$. Likewise, sugary- 1 kernels had higher moisture contents at 20,25,30, and 35 DPP than normal $(P>0.05$; Table 1). Normal mature (9\% moisture) kernels had significantly higher fresh and dry weights than mature sugary- 1 kernels. Some of the differences in kernel dry weights can be attributed to losses in sugary- 1 kernel dry weight during the drydown period of kernel development (after $30 \mathrm{DPP}$ ). The sugary- 1 kernels lost about $8 \%$ of their dry weight during this period, whereas normal kernels lost only $2 \%$. A comparison of means by a Student $t$ test indicated that there was a significant decrease in dry weight in the sugary- 1 genotype $(P>0.01)$, whereas the decrease in dry weight in the normal genotype was not significant. Similar decreases in dry weight by OH43 sugary- 1 kernels during the drydown periods were also observed in trials performed in subsequent years (data not shown). A portion of the reduced dry weight in sugary- 1 kernels is attributed to a decrease in total (1:4),(1:6) $\alpha$-Dglucan (starch + phytoglycogen) in the endosperms (Fig. 1A).

Of the enzyme activities measured in developing kernels, sucrose synthase, UDP-Glc pyrophosphorylase, aldolase, phosphoglucomutase, and phosphoglucoisomerase had increased activity in sugary- 1 kernels in the later stages of kernel development, especially from 25 to 35 DPP (Fig. 1). The enhanced enzyme activities at these stages of kernel development in sugary- 1 kernels may be attributable to the retention of moisture. Cox and Dickinson (1973) may have been observing a similar phenomenon when they described increased hexose kinase activities in shrunken-2 kernels at the later stages of development. The retention of moisture also

Table 1. Fresh weight, dry weight, and percent moisture of normal and sugary-1 OH43 kernels at various days postpollination (DPP). ${ }^{\mathrm{z}}$

\begin{tabular}{|c|c|c|c|c|c|c|}
\hline \multirow[b]{2}{*}{ DPP } & \multicolumn{2}{|c|}{$\begin{array}{c}\text { Fresh wt } \\
(\mathrm{mg} / \text { kernel })\end{array}$} & \multicolumn{2}{|c|}{$\begin{array}{c}\text { Dry wt } \\
\text { (mg/kernel) }\end{array}$} & \multicolumn{2}{|c|}{$\begin{array}{c}\text { Moisture } \\
(\%)\end{array}$} \\
\hline & Normal & sugary-1 & Normal & sugary-1 & Normal & sugary-1 \\
\hline 10 & 80 & $112^{* *}$ & 15 & 16 & 82 & 85 \\
\hline 15 & 139 & $192^{* *}$ & 38 & 35 & 73 & 82 \\
\hline 20 & 255 & $312^{* *}$ & $108^{* *}$ & 91 & 58 & $71^{* *}$ \\
\hline 25 & 295 & $386^{* *}$ & $156^{* *}$ & 142 & 53 & $63^{*}$ \\
\hline 30 & 342 & $466^{* *}$ & $192^{*}$ & 182 & 44 & $61^{* *}$ \\
\hline 35 & 315 & $426^{* *}$ & $207^{* *}$ & 178 & 34 & $58^{*}$ \\
\hline \multicolumn{7}{|l|}{ Mature } \\
\hline kernel & 223 & $186^{* *}$ & $202^{* *}$ & 169 & 9 & 9 \\
\hline
\end{tabular}

${ }^{\mathrm{z}}$ Mean of 30 individual kernels.

*,** Significant difference between normal and sugary-1 at $P=0.05$ and 0.01 , respectively. 

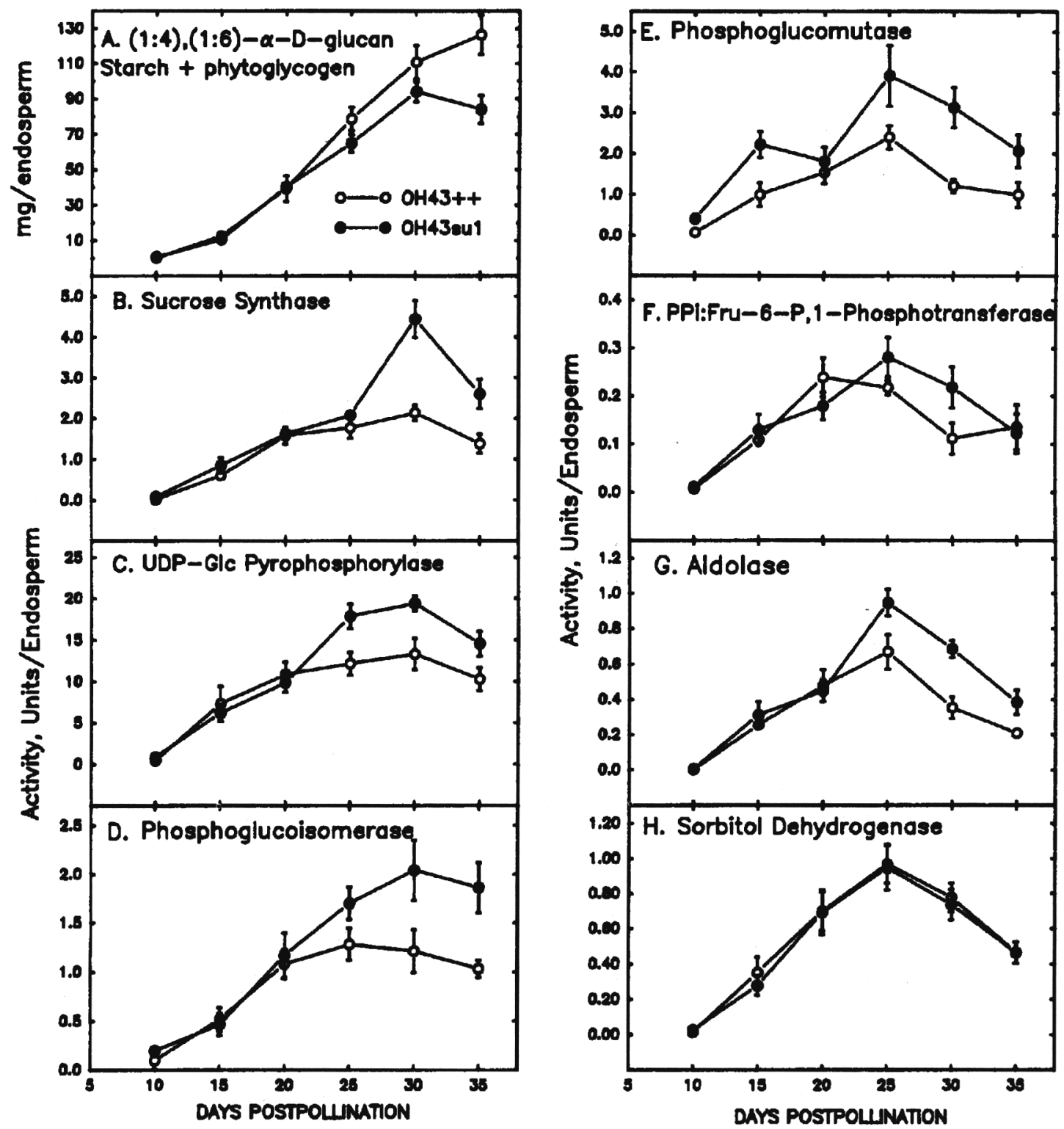

Fig. 1. Profiles of enzyme activities and (1:4 ),(1:6) $\alpha$-D-glucan (starch + phytoglycogen) accumulation in endosperms from normal and sugary-1 OH43 maize during maturation. One unit of activity is the activity required to produce $1 \mu \mathrm{mol}$ of product in $1 \mathrm{~min}$. Error bars indicate SE.

Table 2. Sugar concentrations (mg/g dry wt) in normal and sugary-1 OH43 maize endosperm at various days postpollination (DPP). ${ }^{\mathrm{z}}$

\begin{tabular}{|c|c|c|c|c|c|c|c|c|}
\hline \multirow[b]{2}{*}{ DPP } & \multicolumn{2}{|c|}{ Sucrose } & \multicolumn{2}{|c|}{ Glucose } & \multicolumn{2}{|c|}{ Fructose } & \multicolumn{2}{|c|}{ Sorbitol } \\
\hline & Normal & sugary-1 & Normal & sugary-1 & Normal & sugary-1 & Normal & sugary-1 \\
\hline 10 & 229 & 205 & 117 & 104 & 86 & 82 & 6.6 & $10.6^{* *}$ \\
\hline 15 & 51 & $121^{* *}$ & 4 & $53^{* *}$ & 3 & $33^{* *}$ & 0 & $8.4^{* *}$ \\
\hline 20 & 41 & $124^{* *}$ & 3 & 10 & 3 & 5 & 0 & $5.3^{* *}$ \\
\hline 25 & 41 & $94^{* *}$ & 1 & $15^{*}$ & 2 & 3 & 0 & $3.3^{* *}$ \\
\hline 30 & 19 & $43^{* *}$ & 0 & $14^{*}$ & 0 & 2 & 0 & $3.3^{* *}$ \\
\hline 35 & 19 & $70^{* *}$ & 0 & $33^{* *}$ & 0 & 6 & 0 & $5.0^{* *}$ \\
\hline
\end{tabular}

${ }^{\mathrm{z}}$ Mean of three extractions, each from kernels frcm a separate ear.

${ }^{*, * *}$ Significant difference between normal and sugary-1 at $P=0.05$ and 0.01 , respectively.

may have enhanced respiratory rates in sugary- 1 kernels, which may have contributed to the dry weight losses observed during the dry-down period (Table 1).

An analysis of endosperm sugars during development indicated that sugary- 1 kernels in general had higher sugar concentrations than normal kernels (Table 2). Sucrose and glucose were higher in sugary- 1 kernels than in normal from 15 through 35 DPP, and sorbitol was higher at all dates sampled. Sorbitol is produced by sorbitol dehydrogenase (Doehlert, 1987), whose activity was not significantly different in normal and sugary- 1 endosperm (Fig. 
Table 3. Enzyme activities in crude endosperm extracts from normal (+++) and sugary- 1 (su-1) isolines of OH43 and W64A backgrounds, starchy (A619 x W64A), and sugary- 1 ('Golden' x 'Bantam') maize hybrids. ${ }^{2}$

\begin{tabular}{|c|c|c|c|c|c|c|c|}
\hline Genotype & $\begin{array}{l}\text { Gluco- } \\
\text { kinase }\end{array}$ & $\begin{array}{c}\text { Fructo- } \\
\text { kinase }\end{array}$ & PFP $^{y}$ & $\begin{array}{c}\text { Sucrose } \\
\text { synthase }\end{array}$ & $\begin{array}{c}\text { Total } \\
\text { amylase }\end{array}$ & $\begin{array}{c}\alpha- \\
\text { amylase }\end{array}$ & $\begin{array}{l}\text { Pullu- } \\
\text { lanase }\end{array}$ \\
\hline \multicolumn{8}{|c|}{$[\mu$ mol product $/(\min g$ dry $w t)]$} \\
\hline \multicolumn{8}{|l|}{$\mathrm{OH} 43$} \\
\hline+++ & 0.677 & 0.530 & 2.96 & 23.72 & 5.77 & 1.18 & 0.814 \\
\hline$s u-1$ & 0.570 & 0.570 & 2.70 & 22.60 & 2.56 & 0.24 & 0.212 \\
\hline \multicolumn{8}{|l|}{ W64A } \\
\hline+++ & 0.507 & 0.483 & 3.13 & 31.70 & 8.00 & 2.03 & 0.827 \\
\hline$s u-1$ & 0.423 & 0.380 & 4.60 & 28.00 & 4.00 & 0.30 & 0.300 \\
\hline A619 x W64A & 0.520 & 0.427 & 5.40 & 20.30 & 4.90 & 2.33 & 0.814 \\
\hline Golden $\times$ Bantam & 0.330 & 0.250 & 9.49 & 24.40 & 1.32 & 0.54 & 0.212 \\
\hline
\end{tabular}

${ }^{\overline{ }}$ Mean of three extractions.

${ }^{\text {} P F P ~=~ p y r o p h o s p h a t e: ~ f r u c t o s e ~ 6-p h o s p h a t e, ~ 1-p h o s p h o t r a n s f e r a s e . ~}$
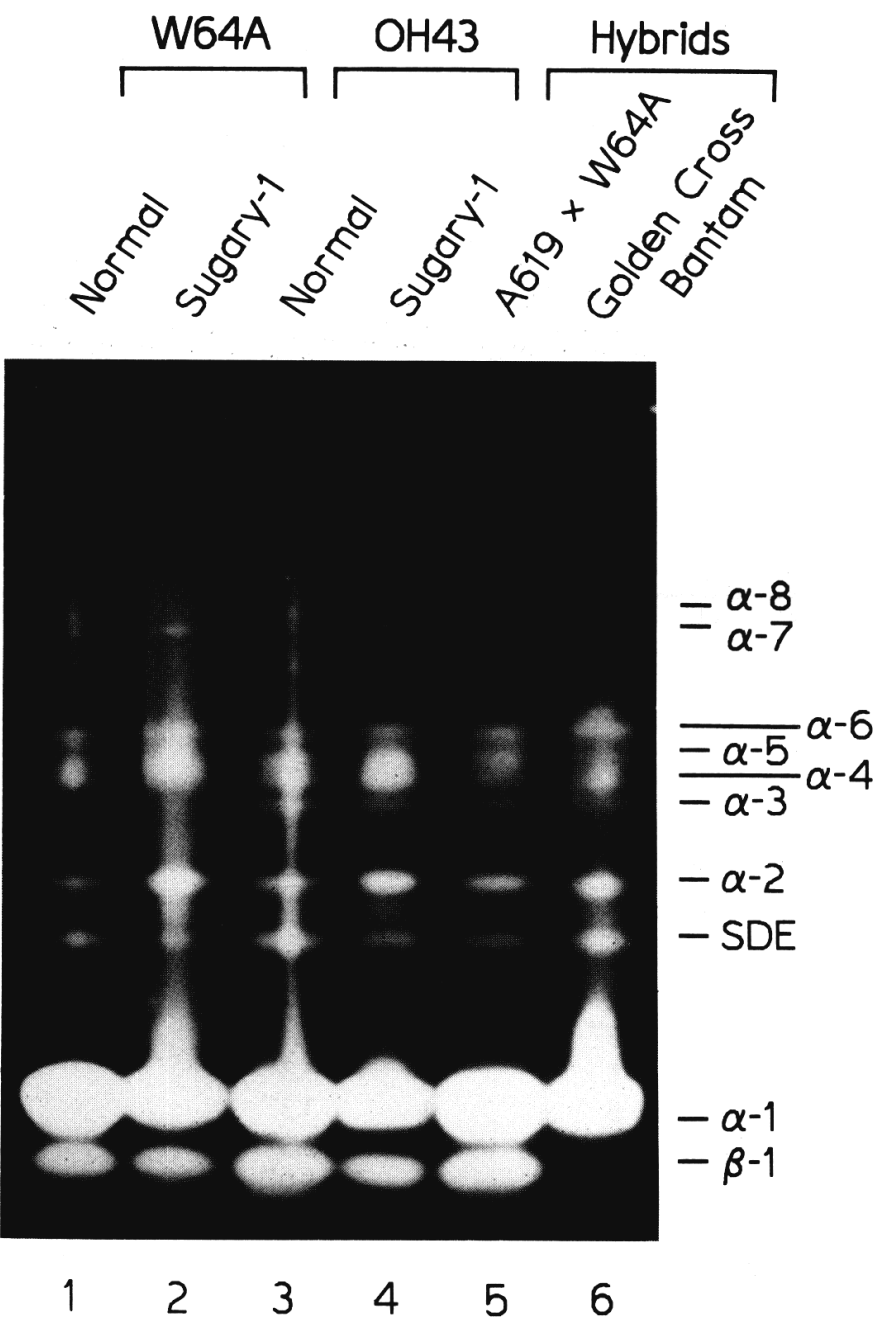

Fig. 2. Starch hydrolytic zymograms from normal and sugary-1 isolines of W64A and $\mathrm{OH} 43$ as well as a sugary-1 hybrid ('Golden' $\mathrm{x}$ 'Bantam') and a normal hybrid (A619 x W64A). $\beta-1$ indicates a $\beta$ - amylase; $\alpha-1,-2,-3,-4,-5,-6,-7$, and -8 are $\alpha$ - amylase isozymes; and SDE (starch debranching enzyme) designates the pullulanase activity band.
1H). Increased sorbitol may be a consequence of the overall increase in sugars. Fructose concentration was significantly higher in sugary- 1 than in normal endosperms only at 15 DPP.

Enzyme activities were measured in 20 DPP kernels of OH43 and W64A normal and sugary- 1 isolines as well as in the sugary1 hybrid 'Golden' $\mathrm{x}$ 'Bantam' and the starchy hybrid A619 x W64A. Data (Fig. 1) indicate that enzyme activities measured at 20 DPP are not confounded by moisture retention effects. There were no consistent differences between sugary- 1 and normal genotypes in activities of glucokinase, fructokinase, PFP, or sucrose synthase (Table 3). However, sugary- 1 genotypes had consistently lower activities of total amylase, $\alpha$ - amylase, and pullulanase (Table 3 ). The lower pullulanase activity observed is consistent with results reported by Pan and Nelson (1984). Zymograms of starch hydrolytic activities from normal and sugary- 1 genotypes indicated no qualitative differences in isozymes of starch hydrolytic enzymes (Fig. 2), although the staining intensity of $\beta$ - amylase from 'Golden' $\mathrm{x}$ 'Bantam' was considerably lower than those of other genotypes. We cannot attribute the observed differences in enzyme activities to the absence of any particular form of enzyme.

We produced reciprocal crosses between sugary-1 and normal lines of $\mathrm{OH} 43$ to produce developing kernels with zero, one, two, and three doses of the sugary- 1 gene. No significant differences in carbohydrate composition were observed until three doses of sugary- 1 gene were present in the developing endosperm. Endosperm containing three doses of the sugary-1 gene had higher soluble sugars and phytoglycogen, decreased starch, and no difference in total carbohydrate concentrations than the others (Table 4). Ayers and Creech (1969) also have shown that three doses of the sugary- 1 gene are necessary for significant accumulation of phytoglycogen.

Differences in enzyme activities in 20 DPP endosperms were

Table 4. Effect of sugary- 1 gene dosage on mature OH43 kernel carbohydrate composition.'

\begin{tabular}{lcccc}
\hline Genotype $^{y}$ & $\begin{array}{c}\text { Soluble } \\
\text { sugars }\end{array}$ & $\begin{array}{c}\text { Phyto- } \\
\text { glycogen }\end{array}$ & Starch & $\begin{array}{c}\text { Total } \\
\text { carbohydrate }\end{array}$ \\
\hline & \multicolumn{4}{c}{$(m g / g d r y w t)$} \\
++ & 44.1 & 9.8 & 658.8 & 712 \\
++ su & 50.2 & 13.7 & 641.5 & 668 \\
su su + & 45.6 & 12.8 & 644.2 & 702 \\
su su su & 87.4 & 452.6 & 192.5 & 732
\end{tabular}

${ }^{\mathrm{z}}$ Mean of four extractions, each from kernels from separate ears.

"Zero, one, two, and three doses, respectively, of the sugary- 1 gene (su). 
Table 5. Dosage effects of the sugary-1 (su) gene on enzyme activities in extracts of endosperms from OH43 kernels harvested 20 days postpollination (DPP). ${ }^{\mathrm{z}}$

\begin{tabular}{|c|c|c|c|c|c|c|c|c|}
\hline Genotype $^{y}$ & $\begin{array}{c}\text { ADP-Glc } \\
\text { pyrophosphorylase }\end{array}$ & PFK & PFP & $\begin{array}{l}\text { Fructo } \\
\text { kinase }\end{array}$ & $\begin{array}{l}\text { Gluco- } \\
\text { kinase }\end{array}$ & $\alpha$-amylase & $\begin{array}{c}\text { Total } \\
\text { amylase }\end{array}$ & $\begin{array}{l}\text { Pullu- } \\
\text { lanase }\end{array}$ \\
\hline \multicolumn{9}{|c|}{ ( $\mu$ mol product/min g dry weight) } \\
\hline+++ & 1.00 & 0.793 & 10.3 & 0.116 & 0.308 & 1.43 & 2.72 & 1.86 \\
\hline$++\mathrm{su}$ & 1.78 & 0.716 & 9.4 & 0.211 & 0.348 & 1.32 & 2.39 & 1.85 \\
\hline su su + & 1.36 & 0.780 & 11.1 & 0.196 & 0.358 & 1.34 & 1.81 & 1.61 \\
\hline su su su & 3.30 & 0.952 & 11.4 & 0.290 & 0.296 & 0.84 & 1.06 & 1.01 \\
\hline
\end{tabular}

${ }^{\mathrm{z}}$ Mean of four extractions. See abbreviation list at the bottom of the first page.

YZero, one, two, and three doses, respectively.

not apparent until three doses of the sugary- 1 gene were present (Table 5). In accordance with data shown in Table 3, total amylase, a-amylase, and pullulanase activities were lower in sugary- 1 kernels than in kernels with either zero, one, or two doses of the sugary- 1 gene, and activities of glucokinase, fructokinase, PFP, and PFK were not affected by the sugary- 1 locus. In addition, ADP-Glc pyrophosphorylase activity increased in endosperms containing three doses of the sugary- 1 gene. Increased ADP-Glc pyrophosphorylase activity also has been observed in endosperms of starch-deficient maize mutants (Doehlert and Kuo, 1990) and in endosperms of high-starch maize lines (Doehlert and Lambert, 1991) and was attributed to increased sucrose levels in these tissues. It is consistent with these studies that the increased sucrose concentration in sugary- 1 endosperm would result in increased ADP-Glc pyrophosphorylase activity. Activities of PFP, glucokinase, fructokinase, total amylase, and pullulanase (Table 5) appear to differ significantly from activities of the same enzymes measured in OH43 endosperms (Table 3). Data from these tables were obtained from corn grown in different years, and we attribute the differences to developmental differences brought about by environmental conditions in these years.

The lack of correlation between the decreased activities of starch hydrolytic enzymes and sugary- 1 gene dosage is inconsistent with the hypothesis that the sugary- 1 mutation encodes the structural genes for any of these enzymes. This observation conflicts with work by Pan and Nelson (1984), who found a close correlation between sugary- 1 gene dosage and pullulanase activity. We have no explanation for this discrepancy, except for the fact that Pan and Nelson (1984) assayed their extracts as ammonium sulfate precipitants at $\mathrm{pH} 7.0$, instead of using crude extracts at $\mathrm{pH}$ 5.0, the optimal $\mathrm{pH}$ for this enzyme (Doehlert and Knutson, 1991). The brittle- 1 mutant also has been reported to contain very low pullulanase activity (Doehlert and Kuo 1990). Since the work of Pan and Nelson (1984), an additional form of starch debranching enzyme of the isoamylase class has been described in developing maize kernels (Doehlert and Knutson, 1991). Interference by phytoglycogen and endogenous amylases has prevented us from testing for isoamylase activity in sugary- 1 endosperms.
A major problem in assaying starch hydrolytic enzymes in sugary- 1 endosperm extracts lies in the probable interference by the water soluble phytoglycogen. We found that aqueous sugary1 extracts are milky from solubilized phytoglycogen in comparison with normal extracts, and contained up to $4 \mathrm{mg}$ phytoglycogen/ $\mathrm{ml}$ (data not shown). This amount represents a significant endogenous substrate pool for starch hydrolytic enzymes and poses other more subtle problems that aggravate attempts to quantitate enzyme' activities. In an experiment to determine the effects of phytoglycogen on starch hydrolytic enzyme activities, we added purified phytoglycogen to normal whole kernel extracts and centrifuged the preparations. We then assayed starch hydrolytic enzymes in the supernatants. We found that this treatment significantly decreased both total and $\alpha$-amylase activitites in the extracts. The mean activity of pullulanase was lower in the phytoglycogen-treated samples; the difference was not significant at $P \leq 0.05$ but was significant at $P \leq 0.1$ (Table 6). Presumably, the amylases bind to the phytoglycogen as they would in a glycogen precipitation commonly used to purify $\alpha$-amylase (Thoma et al, 1971). Centrifugation pellets a portion of the phytoglycogen and with it, a portion of the amylases. Pullulanase may bind to phytoglycogen to a lesser extent, but these results do not account for all of the decreased pullulanase activity found in sugary- 1 extracts. We also have tested the effects of phytoglycogen concentration on pullulanase and amylase activities, and found no effect of phytoglycogen, up to $10 \mathrm{~g} \cdot \mathrm{liter}^{-1}$, on either pullulanase or $\alpha-$ amylase activities, as long as the contribution of phytoglycogen hydrolysis was subtracted from the total hydrolytic activity (data not shown). Thus, we cannot account for all of the decreased pullulanase activity from phytoglycogen interference. It seems likely that the sugary- 1 mutation reduces expression of pullulanase. However, evidence suggests that pullulanase is a monomer, and the multiple forms of pullulanase observed by Pan and Nelson (1984) and others (Toguri, 1991) are different configurations of the same peptide (Beck and Zeigler, 1989).

In conclusion, we have presented several metabolic characteristics that are the consequence of the sugary- 1 mutation, including increased activities of specific enzymes during kernel dry-down,

Table 6. Effect of phytoglycogen on the recovery of extracted starch hydrolytic enzyme activity in corn kernel extracts following centrifugation. All samples were derived from the same normal OH43 whole kernel extract. ${ }^{\mathrm{z}}$

\begin{tabular}{lcccc}
\hline \hline & \multicolumn{5}{c}{ Control } & $\begin{array}{c}\text { Control } \\
\text { + phytoglycogen }\end{array}$ & & \\
\cline { 2 - 4 } Enzyme & \multicolumn{2}{c}{$(\mu \mathrm{mol}$ product/ml extract $\pm \mathrm{SD})$} & & $P$ \\
\hline Total amylase & $0.853 \pm 0.081$ & $0.739 \pm 0.062$ & -9.913 & 0.0050 \\
$\alpha$-amylase & $0.056 \pm 0.021$ & $0.014 \pm 0.001$ & -3.561 & 0.0353 \\
Pullulanase & $0.051 \pm 0.002$ & $0.044 \pm 0.006$ & -2.452 & 0.0669
\end{tabular}

${ }^{\mathrm{z}}$ Mean from three experiments. 
increased ADP-Glc pyrophosphorylase activity at 20 DPP, and decreased starch hydrolytic enzyme activities at 20 DPP. Because these events are correlated with the sugary- 1 phenotype and not the sugary-1 gene dosage, it appears that these events are a consequence of the sugary-1 lesion, rather than the primary effect.

\section{Literature Cited}

Andrew, R.H., R.A. Brink, and N.P. Neal. 1944. Some effects of the waxy and sugary genes on endosperm development in maize. J. Agr. Res. 69: 355-371.

Ayers, E.A. and R.G. Creech. 1969. Genetic control of phytoglycogen accumulation in maize (Zea mays L.). Crop Sci. 9:739-741.

Bernfield, P. 1951. Enzymes of starch degradation and synthesis, p. 379428. In: F.F. Nord (ed.). Advances in enzymology. vol. 12. Interscience, New York.

Beers, E.P. and S.H. Duke. 1988. Localization of a-amylase in the apoplast of pea (Pisum sativum) stems. Plant Physiol. 87:799-802.

Beck, E. and P. Ziegler. 1989. Biosynthesis and degradation of starch in higher plants. Annu. Rev. Plant Physiol. Plant Mol. Biol. 40:95-117.

Boyer, C.D., R.R. Daniels, and J.C. Shannon. 1977. Starch granule (amyloplast) development in endosperm of several Zea mays L. genotypes affecting kernel polysaccharides. Amer. J. Bot. 64:50-56.

Boyer, C.D. and J. Preiss. 1978. Multiple forms of starch branching enzyme of maize: Evidence for independent genetic control. Biochem. Biophys. Res. Acta 80:169-175.

Cox, E.L. and D.B. Dickinson. 1973. Increased hexokinase levels in endosperm of mutant maize. Phytochemistry 12:291-297.

Dickinson, D.B., C.D. Boyer, and J.G. Velu. 1983. Reserve carbohydrates from sugary and sugary extender maize. Phytochemistry 22: 13711373.

Doehlert, D.C. 1987. Ketose reductase activity in developing maize endospenn. Plant Physiol. 84:830-834.

Doehlert, D.C. 1990. Distribution of enzyme activities within the developing maize (Zea mays) kernel in relation to starch, oil, and protein accumulation. Physiol. Plant. 78:560-567.

Doehlert, D.C. and S.H. Duke. 1983. Specific determination of $\alpha$-amylase activity in crude plant extracts containing $\beta$ - amylase. Plant Physiol. 71:229-234.

Doehlert, D.C. and C.A. Knutson. 1991. Two classes of starch debranching enzyme from developing maize kernels. J. Plant Physiol. 138:566-572.

Doehlert, D.C. and T.M. Kuo. 1990. Sugar metabolism in developing kernels of starch-deficient endosperm mutants of maize. Plant Physiol. 92:990-994.

Doehlert, D.C., T.M. Kuo, and F.C. Felker. 1988. Enzymes of sucrose and hexose metabolism in developing kernels of two inbreds of maize. Plant Physiol. 86:1013-1019.

Doehlert, D.C. and R.J. Lambert. 1991. Metabolic characteristics associated with starch, protein, and oil accumulation in developing maize kernels. Crop Sci. 31:151-156.

Erlanger, S.R. 1957. A proposed mechanism for the synthesis of starch from glycogen. Enzymologia 19:273-283.

Gascon, S. and J.O. Lampen. 1968. Purification of the internal invertase of yeast. J. Biol. Chem. 243:1567-1572.

Hodge, J.E. and B.T. Hofreiter. 1962. Phenol-sulfuric acid calorimetric method, p. 388-389. In: R.L. Whistler and M.L. Wolfram (eds.). Methods in carbohydrate chemistry. vol. 4. Academic, New York.

Kakefuda, G. and S.H. Duke. 1984. Electrophoretic transfer as a technique for the detection and identification of plant amylolytic enzymes in polyacrylamide gels. Plant Physiol. 75:278-280.

Kuo, T.M., J.F. VanMiddlesworth, and W.J. Wolf. 1988. Content of raffinose oligosaccharides and sucrose in various plant seeds. J. Agr. Food Chem. 36:32-36.

Morris, D.L. and C.T. Morris. 1939. Glycogen in the seeds of Zea mays (variety Golden Bantam). J. Biol. Chem. 130:535-544.

Pan, D. and O.E. Nelson. 1984. A debranching enzyme deficiency in endosperms of the sugary- 1 mutant of maize. Plant Physiol. 74:324328.

Schoch, T.J. 1957. Preparation of starch and starch fractions, p. 5-17. In: S.P. Colowich and N.O. Kaplan (eds.). Methods in enzymology. vol. 3. Academic, New York.

Steel, R.G.D. and J.H. Torrie. 1960. Principles and procedures of statistics. McGraw-Hill, New York.

Swain, R.R. and E.E. Dekker. 1966. Seed germination studies. I. Purification and properties of $\alpha$ - amylase from the cotyledons of germinating peas. Biochem. Biophys. Acta 122:75-86.

Thoma, J.A., J.E. Spradlin, and S. Dygert. 1971. Plant and animal amylases, p. 115-189. In: P.D. Boyer (ed.). The enzymes. vol. 5. Academic, New York.

Toquri, T. 1991. Changes of a rice debranching enzyme during seed formation and germination. J. Plant Physiol. 137:541-546.

Tsai, C.Y., B.A. Larkin, and D.V. Glover. 1978. Interaction of the opaque2 gene with starch forming mutant genes on the synthesis of zein in maize endosperm. Biochem. Genet. 16:883-896. 